\title{
¿Son conscientes las universidades de los cambios que se están produciendo en la Educación Superior?
}

\section{Are Universities Aware of the Changes that are Occurring in Higher Education?}

Editorial de la revista

Francisco José García-Peñalvo

Departamento de Informática y Automática, Instituto de Ciencias de la Educación, Grupo GRIAL, Director Científico, Editor-In-Chief Education in the Knowledge Society Journal, Universidad de Salamanca, España. fgarcia@usal.es

\section{Resumen}

El editorial de este último número del volumen 17, correspondiente al año 2016, reflexiona sobre los cambios vertiginosos que se están dando en torno a la educación superior, con modelos de gestión y negocio basados en la virtualización de la formación y en una orientación hacia el mercado laboral, que ponen en entredicho el concepto tradicional de Universidad. La pregunta que subyace es si la Universidad, como institución, es consciente de todos estos movimientos y está preparada para dar una respuesta contundente que le permita adaptarse a las nuevas realidades de una Sociedad Digital, sin perder su hegemonía como garante universal de la generación y transmisión del conocimiento científico y humanístico; o, al contrario, fiel a su tradición más conservadora, continúa reforzando el andamiaje de su torre de marfil, alejándose más y más de esta realidad, segura de una posición de privilegio social que entiende inamovible.

Palabras clave

Universidad; Modelos de gestión en la educación superior; Formación virtual; MOOC.

\begin{abstract}
The editorial of this last issue of volume 17 , corresponding to 2016, reflects about the vertiginous changes that are taking place in higher education, with management and business models based on online education and a labour market orientation that challenge the traditional concept of University. The underlying question is whether the University, as an institution, is aware of all these movements and is prepared to give a qualified response that allows it to adapt to the new realities of a Digital Society, without losing its hegemony as universal guarantor of the generation and transmission of scientific and humanistic knowledge; or, on the contrary, faithful to its more conservative tradition, it continues to reinforce the scaffolding of its ivory tower, moving further and further from this reality, secure from a position of social privilege that it understands immovable.
\end{abstract}

\section{Keywords}

University; Higher Education management models; Online education; MOOC.

En el debate de dos de los últimos eventos en los que he participado como conferenciante invitado (García-Peñalvo, 2016a, 2016b) ha surgido la cuestión del liderazgo de la Universidad, entendida como institución, en el contexto de la educación superior, tras aparecer nuevos actores en este ecosistema, como es el caso de Udacity, por citar uno de los ejemplos más conocidos, que proponen ofertas flexibles, de calidad, orientadas al mercado, con promesas de empleabilidad asegurada y seguimiento online.

El origen de este cambio tiene su efecto detonante en los MOOCs (Massive Open Online Courses) (Martínez Abad, Rodríguez Conde, \& García-Peñalvo, 2014; SCOPEO, 2013), que en su pico de 
popularidad en 2012 (Pappano, 2012) fueron objeto de vaticinios como los de Sebastian Thrun, que manifestaba que en 50 años solo quedarían 10 grandes universidades en el mundo (Leckart, 2012). Los Moocs no han tenido, con el paso del tiempo, el efecto disruptivo que se les atribuía (Fidalgo-Blanco, Sein-Echaluce Lacleta, \& García-Peñalvo, 2015; García-Peñalvo, Fidalgo Blanco, \& Sein-Echaluce Lacleta, 2015; García-Peñalvo \& Seoane-Pardo, 2015), pero han provocado una profunda reflexión en los modelos de aprendizaje online de muchas instituciones, incluidas las universidades, y también han abierto nuevos modelos de negocio y quizás una importante brecha entre las universidades que se están adaptando y liderando la innovación en educación abierta (Fidalgo-Blanco, Sein-Echaluce Lacleta, Borrás Gené, \& García-Peñalvo, 2014) y aquellas que siguen sin responder a las demandas de una Sociedad Digital que ya ha transformado la mayoría de los modelos de negocio tradicionales (banca, ocio, cine, música, fotografía, prensa, etc.) y que tiene en la Educación uno de sus mayores campos potenciales de acción.

La Universidad es, y debe seguir siendo, el pilar y garante básico del conocimiento de nuestra Sociedad, formando profesionales de largo recorrido capaces de crecer tanto en el ámbito personal como profesional. Pero, a diferencia de lo que ha pasado hasta prácticamente ayer, este rol de liderazgo en la educación superior, no lo tiene garantizado en una Sociedad Digital en la que el concepto de presencialidad/virtualidad se difumina y se fusiona (García-Peñalvo, 2015), por lo que debe tomar un rol consciente y proactivo que conlleva obligatoriamente tomar decisiones en sus modelos formativos, de gestión de tecnología y de promoción y reconocimiento de su personal docente e investigador.

\section{Contenido de este número}

El primer artículo de este número lleva por título "Desarrollo de competencias emprendedoras mediante iniciativas de aprendizaje basado en proyectos" (Sánchez de Gómez, Ferrero Castro, Conde González, \& Alfonso Cendón, 2016) plantea la aplicación de una metodología de aprendizaje basado en proyectos. Se presenta una experiencia desarrollada durante dos años en los que los estudiantes deben desarrollar proyectos completos en grupos y generar productos reales lográndose resultados positivos en la obtención de las competencias de las materias y en la motivación de los estudiantes.

Ibáñez Quintana y Hoyuelos Álvaro (2016) presentan un estudio para detectar y estudiar las características y prácticas docentes deseadas por el alumnado de primer curso de Grado en la docencia que recibirá en sus asignaturas, comparando las titulaciones en Maestro de Educación Infantil y Primaria de la Universidad de Burgos. Los resultados indican que el alumnado valora más las características profesionales de su profesorado que las personales; y que la imagen transmitida por el profesorado que utiliza las TICs es siempre positiva, generando una opinión favorable de su docencia, y llegándolas a considerar indispensables por parte del alumnado en la enseñanza actualmente recibida. 
Seco y Quintas-Mendes (2016) comparan dos plataformas, OpenStax Connexion y Wikilibros, con el objetivo de identificar las ventajas y desventajas de cada una de ellas como plataforma de producción de Libros Abiertos que se puedan considerar como Recursos Educativos Abiertos (Ramírez Montoya \& García-Peñalvo, 2015) y apoyo a las Prácticas Educativas Abiertas.

El cuarto artículo (Buendía García, Benlloch Dualde, Zahonero Viana, \& Cubel Barea, 2016) presenta una serie de reflexiones sobre el uso de dispositivos tablet (tabletas) en el ámbito de la Enseñanza Secundaria. Por un lado, en el trabajo se plantean ciertas cuestiones sobre el aprovechamiento didáctico de estos dispositivos y las necesidades o requisitos que ello implica. Por otra parte, se trata de extraer una serie de recomendaciones para una aplicación efectiva de este tipo de dispositivos.

Lerís et al. (2016) exploran la percepción de los participantes en MOOCs respecto a sus necesidades de adaptatividad en este tipo de cursos, así como su relación con distintos aspectos de los participantes, como sus perfiles (género, edad, ubicación geográfica y nivel académico), su experiencia previa o conocimiento sobre el tema del MOOC y su motivación para iniciar el MOOC.

El último de los artículos de este número lleva por título “¿Una imagen o mil palabras? Influencia de la extensión de las preguntas y el soporte gráfico en las tasas de éxito y abandono de las pruebas en línea" (Redondo, Regot, Fonseca, Valls, \& Gímenez, 2016), en él se analizan los resultados de más de 20.000 exámenes simulados en línea diseñados para preparar el estudiantado para las pruebas de acceso a la universidad española (selectividad) en la materia de dibujo técnico, correspondientes a las convocatorias de junio y septiembre de 2009 y 2015. Los autores evalúan la influencia de dos aspectos clave en el número de preguntas respondidas correctamente o abandonadas: (a) la presencia o ausencia de una ilustración y (b) la extensión de la pregunta como indicador de la comprensión lectora. Los resultados apoyan que la presencia de una ilustración se traduce en menor número de preguntas abandonadas y mayor número de preguntas respondidas correctamente, mientras que la extensión de la pregunta tiene el efecto contrario.

In the debate after two of the last events in which I have participated as keynote speaker (GarcíaPeñalvo, 2016a, 2016b), the question about the leadership of the University in the context of the higher education, understood as an institution, has arisen, after appearing new actors in this ecosystem (for example the Udacity case to mention one of the best known ones) that propose online, flexible, quality, and market-oriented offers with promises of assured employability.

The origin of this change has its detonating effect in the MOOCs (Massive Open Online Courses) (Martínez Abad, et al., 2014; SCOPEO, 2013), which at its peaks of popularity in 2012 (Pappano, 2012) were the subject of predictions such as those of Sebastian Thrun, who stated that in 50 years there would only be 10 important universities in the world (Leckart, 2012). MOOCs have not had, 
over time, the disruptive effect attributed to them (Fidalgo-Blanco, et al., 2015; García-Peñalvo, et al., 2015; García-Peñalvo \& Seoane-Pardo, 2015), but they have led a deep reflection in the online learning models of many institutions, including universities, but also have opened new business models and perhaps a significant gap between the universities that are adapting and leading innovation in open education (Fidalgo-Blanco et al., 2014) and those that still do not respond to the demands of a Digital Society that has already transformed most of the business models (banking, leisure, cinema, music, photography, press, etc.) and has one of its greatest potential fields of action in Education.

University is, and must remain, the pillar and the basic guarantor of our Society's knowledge, taking out long-distance professionals capable of growing both in the personal and professional spheres. But, unlike what has happened until practically yesterday, this role of leadership in higher education is not guaranteed in a Digital Society in which the concept of presence/virtuality is blurred and merged (García-Peñalvo, 2015), so universities must take a conscious and proactive role that entails mandatory decision making in its models of teaching, technology management and promotion and recognition of its teaching and research staff.

\section{Contents of this issue}

The first article of this issue is entitled "Development of Entrepreneurial Skills through Project-Based Learning Initiatives" (Sánchez de Gómez, et al., 2016) proposes the application of a Project-Based Learning methodology. It presents an experience developed during two years in which the students must develop complete projects in groups and generate real products achieving positive results in obtaining the competences of the subjects and in the motivation of the students.

Ibáñez Quintana and Hoyuelos Álvaro (2016) present a study to detect and analyse the desired characteristics and teaching practices that first year students will be taught in different subjects, comparing Pre-school with Primary Education degree at Burgos University. The results show that the student body values more the professional characteristics of its teaching staff than the personal ones; and the image transmitted by the teaching staff that uses ICT is always positive, creating a favourable opinion of his teaching, and the student body reaches to consider that ICTs are indispensable to nowadays education.

Seco and Quintas-Mendes (2016) compare two platforms, OpenStax Connexion and Wikibooks, in order to identify the advantages and disadvantages of each of them to support the production of Open Books that can be used as Open Educational Resources (Ramírez Montoya \& García-Peñalvo, 2015) in the context of Open Educational Practices.

The fourth paper (Buendía García, et al., 2016) presents a set of reflections about the use of the tablet devices in Secondary Education. On the one hand, the work deals with some issues about the 
didactical deployment of such devices together with their educational requirements. On the other hand, some recommendations are provided to support an effective use of these devices.

Lerís et al. (2016) explore the MOOC participants' perception of their adaptive needs in this type of course, as well as their relationship with different aspects of the participants, such as: profiles (gender, age, geographical location and academic level), previous experience and knowledge about the topic of the MOOC and motivation to start the MOOC.

The last paper of this issue is entitled "One picture or a thousand words? Influence of question length and illustration support on the success and skip rates on online tests" (Redondo, et al., 2016). Authors analyse the results of over 20,000 pre-university mock online quizzes designed to train the students for the Spanish university admission test in the technical drawing subject, corresponding to the June and September intakes of 2009 and 2015. The influence of two key aspects on the questions success and skip rates is assessed: (a) the presence or absence of illustration support and (b) the length of the question as a proxy of reading comprehension difficulty. The results support that the presence of an accompanying illustration in the questions result in fewer skipped questions and mode successful answers, while the length of the question has the opposite effect.

\section{Referencias/References}

Buendía García, F., Benlloch Dualde, J. V., Zahonero Viana, I., \& Cubel Barea, A. (2016). Experiencias en la aplicación de tabletas en Secundaria. Education in the Knowledge Society, 17(4), 75-89. doi:https://doi. org/10.14201/eks20161747589

Fidalgo-Blanco, Á., Sein-Echaluce Lacleta, M. L., Borrás Gené, O., \& García-Peñalvo, F. J. (2014). Educación en abierto: Integración de un MOOC con una asignatura académica. Education in the Knowledge Society (formerly Revista Teoría de la Educación: Educación y Cultura en la Sociedad de la Información), 15(3), 233-255.

Fidalgo-Blanco, Á., Sein-Echaluce Lacleta, M. L., \& García-Peñalvo, F. J. (2015). Methodological Approach and Technological Framework to break the current limitations of MOOC model. Journal of Universal Computer Science, 27(5), 712-734. doi:http://dx.doi.org/10.3217/jucs-021-05-0712

García-Peñalvo, F. J. (2015). Cómo entender el concepto de presencialidad en los procesos educativos en el siglo XXI. Education in the Knowledge Society (EKS), 16(2), 6-12. doi:http://dx.doi.org/10.14201/ eks2015162612

García-Peñalvo, F. J. (2016a). Experiencia MOOCs. Caso de Estudio Grupo GRIAL de la USAL. Paper presented at the Digitalización y MOOCs, motores de innovación en Educación Superior, Campus San 
Joaquín de la Pontificia Universidad Católica de Chile http://repositorio.grial.eu/handle/grial/695

García-Peñalvo, F. J. (2016b). Oportunidades y barreras para el desarrollo de la tercera misión en la sociedad digital. Paper presented at the Jornada 2016 sobre Sociedad Digital y Educación. Cátedra Telefónica-UNIR, Madrid, España. http://repositorio.grial.eu/handle/grial/680

García-Peñalvo, F. J., Fidalgo Blanco, Á., \& Sein-Echaluce Lacleta, M. L. (2015). Tendencias en Innovación Educativa. Paper presented at the III Congreso Internacional sobre Aprendizaje, Innovación y Competitividad (CINAIC 2015), Madrid, España. http://gredos.usal.es/jspui/handle/10366/126559

García-Peñalvo, F. J., \& Seoane-Pardo, A. M. (2015). Una revisión actualizada del concepto de eLearning. Décimo Aniversario. Education in the Knowledge Society, 16(1), 119-144. doi:http://dx.doi. org/10.14201/eks2015161119144

Ibáñez Quintana, J., \& Hoyuelos Álvaro, J. (2016). Expectativas de los/las estudiantes de primer curso comparadas en los Grados en Maestro/a de Educación Infantil y Primaria de la Universidad de Burgos al respecto de las características y prácticas docentes universitarias más deseadas. Education in the Knowledge Society, 17(4), 29-52. doi:https://doi.org/10.14201/eks20161742952

Leckart, S. (2012, March 20). The Stanford Education Experiment Could Change Higher Learning Forever. Wired. Retrieved from http://www.wired.com/2012/03/ff_aiclass/all/

Lerís, D., Sein-Echaluce, M. L., Hernández, M., \& Fidalgo-Blanco, Á. (2016). Participantes heterogéneos en MOOCs y sus necesidades de aprendizaje adaptativo. Education in the Knowledge Society, 17(4), 91109. doi:https://doi.org/10.14201/eks201617491109

Martínez Abad, F., Rodríguez Conde, M. J., \& García-Peñalvo, F. J. (2014). Evaluación del impacto del término "MOOC" vs "eLearning" en la literatura científica y de divulgación. Profesorado. Revista de currículum y formación del profesorado, 18(1), 185-201.

Pappano, L. (2012, November 2). The Year of the MOOC. The New York Times. Retrieved from http:// www.nytimes.com/2012/11/04/education/edlife/massive-open-online-courses-are-multiplying-at-arapid-pace.html

Ramírez Montoya, M. S., \& García-Peñalvo, F. J. (2015). Movimiento Educativo Abierto. Virtualis, 6(12), $1-13$.

Redondo, E., Regot, J., Fonseca, D., Valls, F., \& Gímenez, L. (2016). One picture or a thousand words? Influence of question length and illustration support on the success and skip rates on online tests. Education in the Knowledge Society, 17(4), 111-128. doi:https://doi.org/10.14201/eks2016174111128 
Sánchez de Gómez, L., Ferrero Castro, R., Conde González, M. Á., \&Alfonso Cendón, J. (2016). Desarrollo de competencias emprendedoras mediante iniciativas de aprendizaje basado en proyectos. Education in the Knowledge Society, 17(4), 15-28. doi:https://doi.org/10.14201/eks20161741528

SCOPEO. (2013). MOOC: Estado de la situación actual, posibilidades, retos y futuro. Retrieved from Salamanca, Spain: http://scopeo.usal.es/wp-content/uploads/2013/06/scopeoi002.pdf

Seco, C., \& Quintas-Mendes, A. (2016). OpenStax Connexion versus Wikibooks: Análise Comparativa de plataformas de suporte a Livros Abertos. Education in the Knowledge Society, 17(4), 53-74. doi:https:// doi.org/10.14201/eks20161745374 